\title{
ІВАН ФРАНКО - АНАЛІТИК ГОСПОДАРСЬКОЇ ДІЯЛЬНОСТІ КОРОЛІВСТВА ГАЛИЧИНИ І ВОЛОДИМЕРЇ̈ АВСТРО-УГОРСЬКОЇ ІМПЕРІЇ КІНЦЯ ХІХ ПОЧАТКУ ХХ СТОЛІтТя
}

\begin{abstract}
В пропонованій статті ї̈ авторами розкривається одна із багатогранних сторін геніального Каменяра Галичини, Украӥни і світу Івана Яковлевича Франка (1856-1916), як економіста. Дається огляд його економічних праџь. На сьогодні ияя творча грань генія і творча спадщина Каменяра повністю не розкрита, в порівнянні з його літературною творчістю і громадсько-політичною діяльністю. Він є безперечним автором і засновником української економічної термінології, щэо вже його ставить в ряд з провідними вченими-економістами Украӥни.

Основною метою $і$ завданням пропонованої статті є більш глибоке розкриття творчих здобутків $i$ напрацювань в галузі економіки Івана Франка. Науково-економічний потениіал Каменяра дозволяє використати його праиі, як в науково-прикладному плані, так і практичному, господарсько-економічному житті нашої державі
\end{abstract}

Ключові слова: Іван Франко, вчений-економіст, концепція капіталу, аналіз, громада, політекономія, наймана праияя.

Постановка проблеми. Актуальність проблеми полягає в більш глибокому розкритті особистості І.Я.Франка, як вченого-економіста. На сьогодні ця творча грань генія i творча спадщина Каменяра повністю не розкрита, в порівнянні 3 його літературною творчістю $\mathrm{i}$ громадсько-політичною діяльністю. Ми знаємо досить глибоко І.Франка як поета, письменника, критика, перекладача, політика, агітатора, громадського діяча. В той же час в нього надзвичайно об'ємна спадщина i тематика наукових економічних праць та досліджень. Він $€$ безперечним автором і засновником української економічної термінології, що вже його ставить в ряд з провідними вченими-економістами України. Як вчений він провів прикладний аналіз господарсько-економічного стану Галичини, вивчив соціальний стан селянства і робітників. Заперечуючи диктатуру пролетаріату i революцію взагалі, обгрунтував еволюційний шлях змін у суспільстві. В своїх працях він особливу увагу приділяє аграрним проблемам, найманій праці, капіталу та іншим питанням, які складають велику наукову спадщину нашого

(c) Даньків Йосип Якимович, к.е.н., проф, зав. кафедри обліку i аудиту, ДВНЗ «Ужгородський національний університет», Ужгород, тел.+380506712549; e-mail: yosyp.dankiv@uzhnu.edu.ua Остап'юк Мирослав Ярославович, к.е.н., проф., зав. кафедри обліку і аудиту та фінансів, Карпатський інститут підприємництва університету «Україна», Хуст Закарпатської області, тел.+388098203332; еmail: mirek8844@gmail.com галицького генія, i які ми, розуміючи їх актуальність, і сьогодні, постарається в певній, незначній, мірі викласти в своїй роботі.

Аналіз основних досліджень та публікацій. В пропонованій статті автори поставили за мету дослідити високу авторитетність наукових економічних праць І.Я.Франка. Його наукова спадщина в цій галузі несе в собі величезний потенціал, який вимагає свого розкриття, висвітлення, розуміння і звичайно практичного використання. Це якраз той західний вітер, який повинен вдихнути наша економіка.

В своїй більшості наші вчені економісти продовжують базуватись на старій совковій заквасці. Тому і економічні праці Каменяра стали в основному об'єктом дослідження істориків і лише частково економістів 3 економічної теорії таких як: Басс I.I., Вірник Ф.Ф., Голубовська Є.А.. Злупко С.М., Каспрук А.А,, Корнійчук Л.Я., Кравець М.М. В навчальному посібнику 3 історії бухгалтерського обліку $[8,9]$. автори цієї статті використали матеріали праць І.Я.Франка «Громадські шпихліри і шпохліровий фонд у Галичині у 1784-1840 p.p.». Інші не працюють, хоча посилань на автора, використовують його здобутки і напрацювання. Ніде і ніхто навіть словом не обмовився, що громади, якими ми так зараз пишаємося, це напрацювання i обгрунтування - нікого іншого як І.Я.Франка. Напевно тому, що його громади пропагували не революційний, а еволюційний шлях розвитку суспільства. Це лише один епізод, а їх безліч. В пропонованій статті автори старались їх 
розкрити. Адже хто не хоче знати минулого, той не вартий майбутнього.

Формування цілей статті. Опираючись на поставлену мету основною ціллю і завданням нашої праці є більш глибоке розкриття творчих здобутків і напрацювань, в галузі економіки, І.Я.Франка. Науково-економічний потенціал Каменяра дозволяє використати його праці, як в науково-прикладному плані, так і практичному, господарсько-економічному житті нашої державі.

У статті на емпіричному і теоретичному рівнях дослідження використані загальнонаукові методи, зокрема, індукція і дедукція для аналізу економічних поглядів Івана Франка.

Опис основного матеріалу дослідження. Перед тим, як приступити до викладу основного матеріалу, нашим обов'язком і необхідністю є подання історико-географічної справки про територію тієї частини України, де народився І.Я.Франко. Колись це було Галицько-Волинське князівство, яке з 1772 року в складі АвстроУгорської імперії називалось Королівство Галичини та Володимирії, але до 1918 року, як корінний край, складова Габсбурської монархії. Як і колись так і сьогодні він поділяється на західну або панську (Підкарпатське, Малопольське і частина Сілезького воєводств) i східну або українську (Івано-Франківська, Львівська, Тернопільська, без північних районів області) частини. Східна або українська Галичина $\epsilon$ частиною Західної України, яка ще включає в себе Волинську, Рівненську, закарпатську i Чернівецьку області. Як західна так і східна Галичина в етнографічних межах має площу 55700 км² $^{2}$ центром Галичини всієї і східної $\epsilon$ місто Львів, а західної Краків. Край надзвичайно неоднорідний за діалектичними та етнографічними особливостями в частині українського населення. Крім нього тут також проживали і проживають поляки, євреї та інші народи. За часів діяльності І.Я.Франка ми маємо цікаві дані людності (населення) Галичини, як східної так і західної, згідно австрійського перепису на 1880 р.:

- Східна Галичина: українців - 2427234 чол.; поляки - 801629 чол.; євреї - 521903 чол.; інші національності - 36170 чол.

- Західна Галичина: поляки - 1896375 чол.; українці - 89308 чол.; євреї - 164029 чол.; інші національності - 9763 чол.

Як бачимо, на східній Галичині переважно українське населення, а на західній - польське.

Національна різношерстість Австро-Угорської імперії вимагала від іiі керівництва дотримуватись ліберальної політики щодо розвитку народів і національних меншин імперії. В Галичині діяли українські гімназіі, преса, видавалась українська література. Багато українців 3 східної України навчались в Галичині, так як там була заборонена царизмом українська мова. В таких умовах жив і творив тоді І.Я.Франко. великий вплив на формування економічного світогляду його економічних поглядів мали вчення соціалістівутопістів, Лассаля, Дж.Міля та інших. 3 середини 70-х років XIX ст., ще в студентські роки I.Франко захоплюється марксизмом. Будучи хорошим аналітиком, І.Франко популяризував марксистську економічну теорію, одночасно сприймаючи їі лише в певній мірі. Політекономію він називав «суспільною економією» вважаючи, що вона займається лише вивченням економічних законів. Основними працями Каменяра 3 економіки є «Злидні Галичини в цифрах», «Спір о дефіциті», «Крайовий бюджет», «Про працю», «Панщина та ii скасування в Галичині», «Громадські штихліри i штихліровий фонд у Галичині у 1784-1940 p.p.», «Промислові робітники східної Галичини й їх плата 1870 р.», «Земельна власність у Галичині», «Еміграція галицьких селян», «Селянських рух у Галичині», «Гримайлівський ключ в 1800 р.», «Селянський страйк в Східній Галичині». В основному економічні праці Франка присвячені стану селянства i робітництва в умовах АвстроУгорської імперії. Тільки поверхове знайомство і аналіз його праць, як економіста викликають захоплення i здивування. Не маючи фундаментальної економічної освіти, його спадок економічних праць настільки широкий i об'ємний, що не тільки, за глибиною змісту, не поступається працям провідних економістів того часу, але в багатьох аспектах перевершує їх. Величезною заслугою нашого Галицького генія була розробка ним української політикоекономічної термінології, так як в Україні переважно застосовувались російські, польські, німецькі терміни. Щодо свого ставлення до революцій взагалі i до соціально-економічної зокрема, I Франко заперечував К.Маркса повністю про ідею диктатури пролетаріату. Він трактував суспільство, як природу, яка терпить еволюційні, а не революційні зміни. В основу суспільства він закладає не сім'̈, а громаду, яка включає в себе певну кількість родин. Громада виробничо-господарська, суспільно-економічна одиниця суспільства. Всі зміни відбуваються через громади як в суспільстві, так і економіці. Громада також адміністративна одиниця в державі. Та про що говорив І.Я.Франко більше як 100 років тому матеріалізується в нашому українському суспільстві сьогодні. Але про те, що основоположником громад був І.Я.Франко в нас ніхто і не згадав і не збирається. Використовуючи в своїх працях статистичні і бухгалтерські дані, 
Каменяр їх глибоко аналізує і всебічно вивчає. «Вся вартість статистичних виводів, - зазначає I.Франко у статті «Статистика яко метода і яко наука», - залежить в першій лінії од правдивості первісних даних статистичних» [9, с.251]. Саме достовірні дані дають можливість провести об'єктивний аналіз будь-чого в т.ч. i господарської діяльності. Наукова спадщина I.Франка багата різноманітною, економічною проблематикою з економічної теорії, економічної історії, фінансів, обліку, статистики, банківської справи та інших галузей економіки.

«.... Галичина, особливо Галицьке Поділля, 3 відмінним чорноземом мав бути аграрним сектором економіки тодішньої Австро-Угорської імперії, а не аграрно-сировинним придатком. Знаючи земельний кадастр Європи, чорнозем Західної України ніяк не міг використовуватись під інші галузі економіки, окрім сільського господарства.

Про це йдеться, зокрема у відомій економічній праці Івана Франка «Громадські шпихліри i шпихліровий фонд у Галичині у 1784-1840 р.р.». Не будучи економістом, Іван Франко прекрасно вивчив питання диференційної ренти та дешевої робочої сили, факторів, які ставили галицький сільськогосподарський ринок поза всякою конкуренцією в Європі.

Безумовно, що в усьому товарному виробництві, і це залишилось і на сьогодні, західний регіон завжди виділявся своїм аграрним сектором...» [8, с.191-192].

Організаційно економічно-господарськими одиницями в Галичині були поміщицькі маєтки 3 прилеглими сферами та фільварками, а також містечками i містами, 3 ремісничими майстернями, дрібними підприємствами, млинами, корчмами, ярмарками, торговицями, базарами.

Якщо взяти Галицьке Поділля, то тут переважно рослинництво, як загальне, так i спеціалізоване, в гірських районах Галичини, а також Буковини i Закарпаття переважало тваринництво. Так на Тернопільщині типовим фільварковим господарством був Гримейлівський ключ - власність графів Потоцьких. В своїй праці «Гримейлівський ключ в 1800 р.» Іван Франко описує організацію і діяльність цього маєтку, його доходи від вирощування культур вузької спеціалізації. В своїх економічних працях I.Франко зазначає, що поміщицькими маєтками в основному володіла польська аристократія, крім фільварків графів Потоцьких, багато сільськогосподарської продукції вироблялось фільварковими господарствами графів Лянцкоронських. Про це в своїх працях зазначає I.Франко, користуючись звітними даними управителів цих фільварків.
У фільварковому сільському господарстві розвивались і промислові підприємства. Як правило, це були підприємства харчової промисловості - борошно-мельна, горілчана, пивоварна, цукроваріння, шкіряне виробництво.

Крім підприємств харчової промисловості також розвивались такі галузі, як нафтодобувна, добре описана I Франко в його творі «Борислав сміється», залізоробна, лісова, виробництво будівельних матеріалів, та інші.

Вивчаючи товарне виробництво, товарний i грошовий обіг, I Франко їх вважав історичною передумовою виникнення, розвитку та існування капіталу. «Під капіталом - наголошує І.Франко розуміємо не тільки гроші, що дають проценти але усякі інші достатки, яких власник не вивчає безпосередньо, але які таким або іншим способом мають давати йому прибуток». В своїй роботі «Про працю» І.Франко безперечно вважав, що капіталістичне виробництво як промислове, сільськогосподарське та інші його види і форми базуються на найманій праці. «Робітник, - писав Франко, - мусить затим бути свобідним не лише правно, але й економічно, тобто мусить бути не тільки кріпакам, але й пролетарієм».

Наші українські вчені, в своїй більшості від захоплення тим, що І.Я.Франко пропагував ідеї марксизму. Так, в молоді роки особливо, i особливо тоді, коли була в нього необхідність засвоїти курс політекономії. Взагалі економічні погляди Франка 3 віком постійно еволюціонували. Так, що зовсім не Марксист наш Франко. Навіть в молоді роки Каменяр критикував цілий ряд марксистських викладок, категорично заперечував диктатуру пролетаріату, a згодом науково обгрунтував i критикував методологічні засади марксистських економічних постулатів, які вели в «Глухий Кут». Наслідуючи в молоді роки Драгоманова, згодом Маркса i Енгельса, в зрілий період свого життя він став критиком марксизму.

Кооперативи, спілки, засновані на основі приватної власності, на засоби виробництва i розподіл стосовно до вкладеного паю, Франко не сприймав це, як соціалізм. Взагалі він застерігав молодь від фальшивих марксистських фраз. Велика заслуга вченому, в проведені ним аналізу методології марксизму, це не тільки українське, але й світове надбання. Будучи великим патріотом, він вважав, що національний інтерес кожного освідченого українця мати зацікавленість щодо об'єктивності трактування, соціально-економічних проблем, пошуку вірного шляху в трактуванні їх суперечливості.

Висновки та перспективи подальших досліджень. В пропонованій статті автори намагались, досить поверхово, на що звернемо 
увагу в майбутніх наших дослідженнях, розкрити генія І.Я.Франка, як економіста. Сучасним нашим вченим-економістам необхідно скористатись спадщиною І.Я.Франка, його методологією щодо вивчення економічної думки в Україні, в еволюційній і історичній послідовності.

Незважаючи на те, що цілий ряд марксистських постулатів Франко прийняв правда 3 своїми змінами щодо капіталу, класів, додаткової вартості, великого виробництва в противагу дрібному і т.д., він відкидав твердження марксистів про необхідність пролетарської революції. Основний акцент робив на громаду, як основну господарську одиницю, підтримував повну децентралізацію в керівництві державою. Також він зовсім не сприймав диктатуру пролетаріату, особливо у веденні сільського господарства 3 позиції цієї диктатури. Історія довела трагізм такого підходу (Голодомор 30-х років в Україні).

Земля має належати членам громади, підприємства - робітникам, які в них працюють. Економічні погляди I. Франка - це ціла епоха в історії економіки країни, яка потребує подальшого глибокого вивчення і освідомлення через осмислення.

\section{ПЕРЕЛІК ВИКОРИСТАНИХ ДЖЕРЕЛ}

1.Басс I.І. Іван Франко: життєвий та творчий шлях / I.I. Басс, А.А. Каспрук. - К.: 1983.- 455 с.

2.Вірник В.Ф. Економічні погляди І.Я.Франка / В.Ф. Вірник, Є.А. Голубовська. - К.: 1956.

3.Даньків Й.Я. Історичні нариси обліково-правові культури: Європа і Україна (від зародження до наших днів): монографія / Й.Я.Даньків, М.Я.Остап’юк. - Ужгород: вид-во УжНУ «Говерла», 2015. - 160 с.

4.Злупко С.М. Іван Франко - економіст / С.М. Злупко. Львів: МП «Слово», 1992. - 208 с.

5.Корнійчук Л.Я. Історія економічної думки: навчальний посібник / Л.Я. Корнійчук. - К.: КНЕУ, 2004. - 432c.

6.Кравець М.М. Іван Франко - історик України / М.М. Кравець.- Львів: Вид-во Львівського університету, 1971. $-204 \mathrm{c}$.

7.Нестерів В.Т. Упрощене книговодство й податки / В.Т. Нестеров. - Львів: 1935. - 128с.

8.Остап’юк М.Я. Історія бухгалтерського обліку: навчальний посібник / М.Я.Остап'юк, М.Р.Лучко, Й.Я.Даньків // Друге видання, випр.і доп.- К.: Знання, 2009. - 278c.

9.Франко І. Зібрання творів у п’ятидесяти томах. - К.: Наукова думка, 1984. т.44 Кн.I. - 695с.

\section{REFERENCES}

1. Bass, I.I. (1983). Ivan Franko: zhyttyevyy ta tvorchyy shlyakh [Ivan Franko: the life and creative way]. Kyyiv [in Ukrainian].

2. Virnyk, V.F. (1956). Ekonomichni pohlyady I.Ya. Franka [Economic views I.Ya. Franko]. Kyyiv [in Ukrainian].

3. Dan'kiv, Yo.Ya. (2015). Istorychni narysy oblikovo-pravovi kul'tury: Yevropa i Ukrayina (vid zarodzhennya do nashykh dniv) [Historical essays of accounting and legal cultures: Europe and Ukraine (from the birth to our days)]. Uzhhorod: Vyd-vo UzhNU «Hoverla» [in Ukrainian].

4. Zlupko, S.M. (1992). Ivan Franko - ekonomist [Ivan Franko - the economist]. L'viv: MP «Slovo» [in Ukrainian].

5. Korniychuk, L.Ya. (2004). Istoriya ekonomichnoyi dumky: navchal'nyy posibnyk [History of economic thought: a textbook]. K.: KNEU [in Ukrainian].

6. Kravets, M.M. (1971). Ivan Franko - istoryk Ukrayiny [Ivan Franko - the historian of Ukraine]. L'viv: Vyd-vo L'vivs'koho universytetu [in Ukrainian].

7. Nesteriv, V.T. (1935). Uproshchene knyhovodstvo y podatky [Simplified bookkeeping and taxes]. L'viv [in Ukrainian].

8. Ostapyuk M.Ya. (2009). Istoriya bukhhalters'koho obliku: navchal'nyy posibnyk [History of accounting: a textbook]. K.: Znannya 2009 [in Ukrainian].

9. Franko, I. (1984). Zibrannya tvoriv u pyatydesyaty tomakh [Collected works in fifty volumes]. K.: Naukova dumka [in Ukrainian].

Одержано 10.09.2018 p. 